\title{
111. CRによる中手骨骨塩量測定の検討（フィルム法との比較）
}

Metacarpal bone densitometory by computed radiography(comparison with film method)

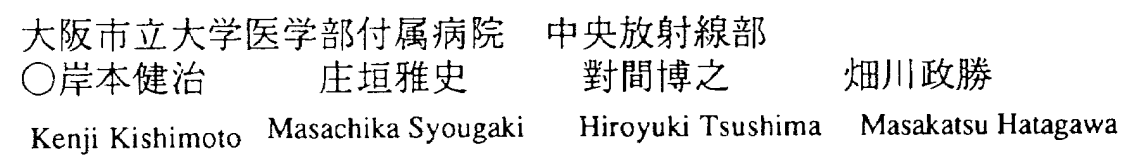

（目的）我々の施設ではX線撮影での全西Computed Radiography（CR）化が行わ机いるにもかかわらず、CRフィル ムからの骨塩量の测定は誤差が大きいという理由のため、MD法には增感紙一フィルム系を朋いて掓影されている。

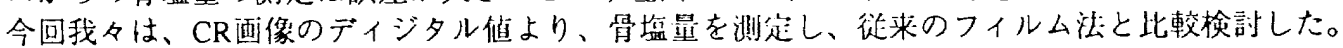

（方法）フィルム法とCR法の測定法

フィルム法は増感紙ーフィルムで摄影された中手骨の写真を2種類の専用装置を用いて骨塩量を求めた。フィルム 法Aは帝人社より商品名ボナライザーとして発売されている装㯰でCXD法とよばれるものである。フィルム法 B は 中外製薬が開発した、DIP法で测定したものである。

CR法はイメージングブレートで撮影された中手骨のディジタル值より、画像処理装置HIC652の計測ソフト

(mesurement2)を用いて骨塩量を求めた。この計湘ソフトは眝士写真フィルム（株）が開発したものを㧍借りした。

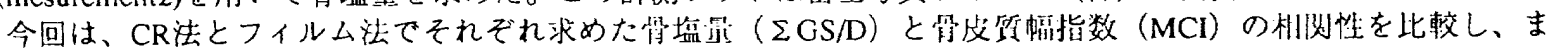

た、变動係数を用いてそれぞれの湘定䊑淁を州べた。

(結果) 1、CR法とフィルム法との相米性

Fig.1にCR法とフィルム法Aとの相関を表わしたグラ フを示す。(a)は骨塩量のグラフで、絴蟿にCR、横軸 にフィルム法Aの值をとり、测定数は28例。グラフ上 の直線は 2 つ值の近似を示す、回帰淔線である。相 関係数Rは 0.867 と高い值を示し、CR法とフィルム法 $\mathrm{A} の$ 骨程量の値は高い相関関係がある。(b)の骨皮質幅 指数MCIで、相関係数は0.711とある程度高い相関関 係にあるといえる。

同様に、Fig.2にCR法とフィルム法Bとの相関を示す。 测定数は8例で、(a)骨塩量の相関係数は 0.953 と非常に 高い值を示している。しかし、(b)MCIでは、相関係数 は0.368 と低い值となっている。この原因は、測定数 が少ないことと、CRのサンプリング間隔が大きいた めであると考えられる。

2、测定精度

Table.1に変動係数CV值を求犯結果を示す。际現性 として、同じ中手骨のファントム写真を10枚撮影し、 それを1回づつ測定したときのCV值は、CRの骨塩量 は2.73\%、フィルム法Aでは2.34\%となり、ほほ同じ 值となった。また、CRのMCIは $3.87 \%$ 、フィルム法 $\mathrm{A}$ では $1.57 \%$ となり、CRが高い值となった。次に、同時 再現性として、1枚の試料を10回測定したときの変動 係数は、CR法、フィルム法A、フィルム法Bの骨塩 量、MCIはいずれも2\%以下で非常に高い測定精度で あった。

（結論）CR法を用いて測定した骨塩量はフィルム法 との相関があった。測定時の変動係数は骨塩量 $3 \%$ 以 下、骨皮質幅指数は4\%以下であった。以前のマイク ロデンシトメータを用いてのMD法の変動係数が䄪 $5 \%$ であったことを考えるとCRでの骨塩星测定は可能で あると考える。

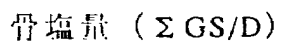

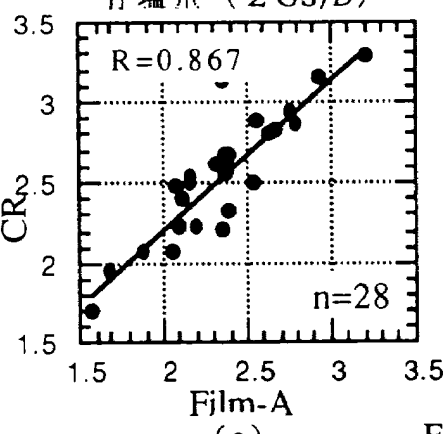

(a)

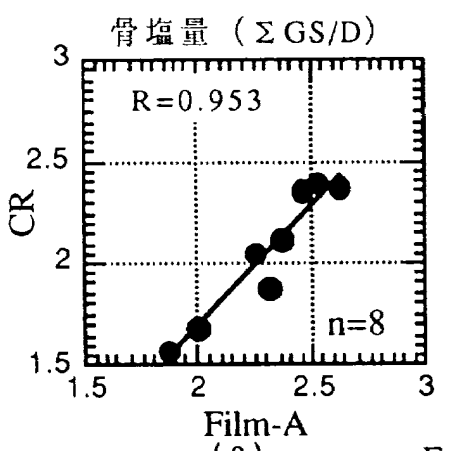

(a) 护尔所幅指数 (MCI)

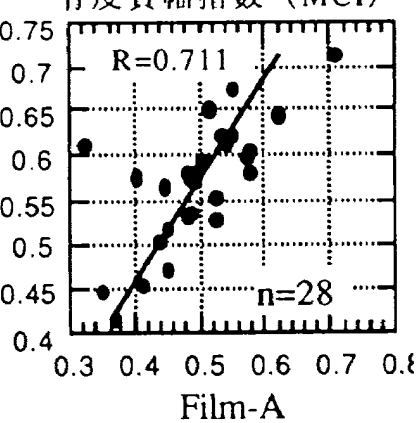

(b)
Fig. 1

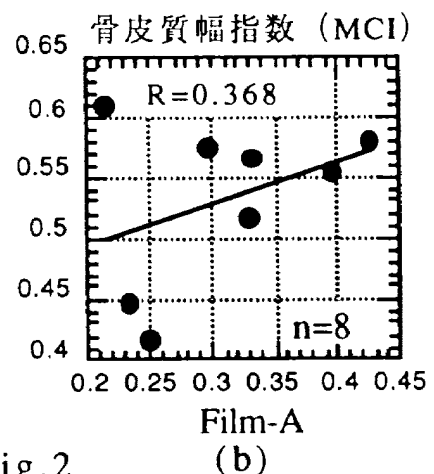

Fig. 2
再現性

( 1 ）回提影、1 回湘定

骨塩量 MCl

$\begin{array}{cc}\text { CR 法 } & 2.73 \\ \text { フィルム法A } & 2.34 \\ \text { フィルム法B } & -\end{array}$

3.87

1.57

- $\quad 0.80$

Table.1
同時再現性 (1回撮影、10回測定)

骨塩量 $\mathrm{MCl}$ $1.60 \quad 0.84$

$0.48 \quad 1.70$
$0.80 \quad 1.88$ 